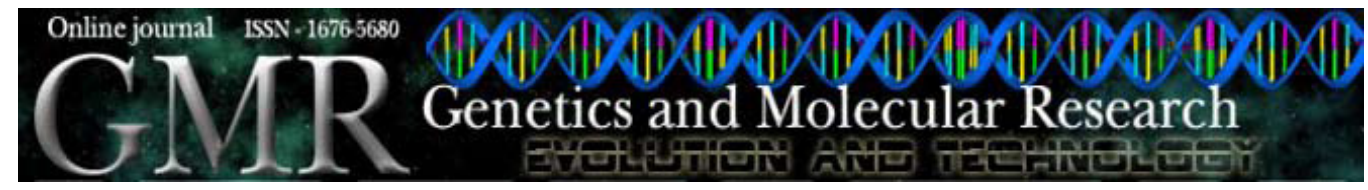

\title{
An investigation of the relationship between serotonin transporter gene promoter polymorphism and psoriasis susceptibility in a Thai population
}

\author{
T. Tencomnao ${ }^{1}$ and J. Wongpiyabovorn ${ }^{2,3}$ \\ ${ }^{1}$ Center for Excellence in Omics-Nano Medical Technology Development Project, \\ Department of Clinical Chemistry, Faculty of Allied Health Sciences, \\ Chulalongkorn University, Bangkok, Thailand \\ ${ }^{2}$ Immunology Unit, Department of Microbi ology, \\ Faculty of Medicine, Chulalongkorn University, Bangkok, Thailand \\ ${ }^{3}$ Lupus Research Unit, Chulalongkorn University, Bangkok, Thailand \\ Corresponding author: T. Tencomnao \\ E-mail: tewin.t@chula.ac.th
}

Genet. Mol. Res. 9 (4): 2275-2282 (2010)

Received July 20, 2010

Accepted September 12, 2010

Published November 23, 2010

DOI 10.4238/vol9-4gmr920

\begin{abstract}
The serotonin transporter (5-HTT) is of great significance in the control of the serotonergic system, and its expression is known to be upregulated in psoriasis, a chronic or recurrent inflammatory skin disease. We investigated a possible association between the 5-HTT gene-linked polymorphic region (5-HTTLPR) and psoriasis in a Thai population. One hundred and fifty-six psoriatic patients and 156 unrelated healthy controls from Bangkok were genotyped using PCR. We found no overall differences in genotype distributions or allele frequencies between the two groups. In addition, when subgroups of psoriatic patients classified by either onset or severity were analyzed, no significant association between this polymorphism and any subgroup
\end{abstract}


was observed. We conclude that 5-HTTLPR is not associated with susceptibility to psoriasis in this Thai population.

Key words: Serotonin transporter gene-linked polymorphic region; Association study; Serotonin transporter; Genetic polymorphism; Psoriasis; Thai population

\section{INTRODUCTION}

Psoriasis, a chronic inflammatory skin disorder, is characterized by an excessive proliferation and abnormal differentiation of keratinocytes and affects approximately $2-4 \%$ of the population worldwide. Since psoriasis arises in connection with stress and mood disorders (Peters et al., 2000; Griffiths and Richards, 2001) and sometimes has been shown to be aggravated in patients after therapy with antidepressants (Barth and Baker, 1986; Osborne et al., 2002; Tan Pei and Kwek, 2010), the pathophysiological role of serotonin (5-hydroxytryptamine, 5-HT) has received substantial attention. Fundamentally, 5-HT is not only synthesized by enterochromaffin cells of the gut and the serotonergic neurons of the brain, but also other cells including lymphocytes (O'Connell et al., 2006). Since 5-HT is accumulated in the platelets and released at inflammatory sites (Geba et al., 1996) and platelet functions have been shown to be associated with dermal diseases (Kasperska-Zajac et al., 2008), the potential participation of 5-HT in psoriasis is strongly supported. Based on the experimental evidence that stress and stress-related hormones promote 5-HT synthesis (Azmitia Jr. and McEwen, 1969; Azmitia et al., 1993), 5-HT may therefore serve as a critical mediator in a neuro-immunocutaneous-endocrine model (O'Sullivan et al., 1998).

The serotonergic system, which consists of 5-HT-producing cells, 5-HT receptors (5HTR) and 5-HT transporters (5-HTT), may play an important part in psoriasis. In supporting this assumption, we formerly noticed a comparable 5-HT level in serum of psoriatic patients and healthy controls, but a significant decrease of 5-HT was observed in the patients' platelets (Tencomnao et al., 2007). Huang et al. (2004) demonstrated that expression of 5-HT was significantly higher in the prickle cells, sweat gland cells, sebaceous gland cells, and hair roots of the lesions in the progressive stage of psoriasis than in the static stage, while no expression of 5-HT was detected in the specimens of normal skin. Accordingly, 5-HT has been considered one of the modifiers of pruritus in psoriasis (Reich and Szepietowski, 2007). Regarding another component of this particular scheme, it was demonstrated that expression of 5-HTR type 2A (5-HTR2A), a mediator of the downstream effects of 5-HT, was significantly higher in involved and noninvolved psoriatic skin than that of normal skin, as involved psoriatic skin had the highest 5-HTR2A level (Nordlind et al., 2006), thereby supporting its molecular role in promoting cell proliferation (Azmitia, 2001). Most recently, the $-1438 \mathrm{~A}$ allele of the $-1438 \mathrm{~A} / \mathrm{G}$ polymorphism of the 5-HTR2A gene was shown to be associated with late-onset psoriasis (Ronpirin et al., 2010).

In controlling the duration and potency of the interactions between 5-HT molecules and their receptors, 5-HTT (a member of the $\mathrm{Na}^{+} / \mathrm{Cl}^{-}$-dependent membrane transporter family) modulates serotoninergic neurotransmission by active reuptaking of 5-HT from synaptic cleft into presynaptic nerves (Amara and Pacholczyk, 1991). The 5-HTT gene, which has the official gene symbol SLC6A4 (solute carrier family 6 [neuro-transmitter transporter, serotonin], member 4), spanning a 37.8-kb region on chromosome 17q11.1-12, comprises 14 exons and codes 
for a protein of 630 amino acids with 12 putative transmembrane domains (Ramamoorthy et al., 1993). Interestingly, it is worth mentioning that the psoriasis locus has been mapped to the chromosome 17q terminus (Tomfohrde et al., 1994; Hwu et al., 2005). 5-HTT gene expression has been found in both serotoninergic neurons and platelets with identical sequences (Lesch et al., 1993). To date, the most well-characterized and extensively studied polymorphism in this gene is a 44-bp insertion/deletion in the promoter region termed the 5-HTT gene-linked polymorphic region (5-HTTLPR) (Lesch et al., 1994; Heils et al., 1996). With regard to its functional significance, the long (1) allele of 5-HTTLPR has been shown to generate higher transcriptional activity than the short (s) allele in numerous cells including the human placental choriocarcinoma cell line (Heils et al., 1996), lymphoblast cell line (Lesch et al., 1996) and immortalized serotonergic raphe neurons (Mortensen et al., 1999). As far as psoriasis is concerned, the expression of 5-HTT has been recently found redistributed in the keratinocytes of involved skin regions with not only higher numbers of 5-HTT-positive dendritic or round mononuclear cells in the epidermis of involved psoriatic skin, but also higher numbers of 5-HTT-positive round inflammatory cells in the dermis of involved psoriatic skin when comparing to either non-involved psoriatic skin or normal skin (Thorslund et al., 2009). Therefore, we examined the possible association between 5-HTTLPR and psoriasis in a Thai population.

\section{MATERIAL AND METHODS}

\section{Subjects}

We successfully genotyped genomic DNA samples obtained from 156 Thai patients with psoriasis diagnosed clinically by experienced dermatologists at King Chulalongkorn Memorial Hospital, Bangkok and Sappasitprasong Hospital, Ubon Ratchathani, and from 156 unrelated healthy Thai volunteers without a family history of psoriasis recruited from the National Blood Center, Thai Red Cross Society and from the Faculty of Allied Health Sciences, Chulalongkorn University. Each patient was classified according to the onset of disease: early onset ( $<40$ years of age) or late onset $(\geq 40$ years of age). To address the severity of psoriasis, the Psoriasis Area and Severity Index (PASI) was used to classify the psoriatic patients into two different levels: level $1=$ PASI $<10$; level $2=$ PASI $\geq 10$. The Ethics Committee of Medical Experiments on Human Subjects (Faculty of Medicine, Chulalongkorn University) approved the study. Informed consents were obtained from all participants prior to inclusion in the study. The characteristics of the subjects are summarized in Table 1.

\section{DNA isolation}

DNA was extracted from leukocytes collected with ethylenediaminetetraacetic acid (EDTA) as an anticoagulant, using either the salting-out method or the FlexiGene DNA kit (Qiagen GmbH, Hilden, Germany).

\section{Genotyping of the 5-HTTLPR polymorphism}

Genotyping of the 5-HTTLPR polymorphism was performed by polymerase chain reaction (PCR) using Taq PCRx DNA polymerase (Invitrogen, Carlsbad, CA, USA). The oligonucle- 
otide primers (5-HTTLPR-forward: 5'-GGCGTTGCCGCTCTGAATTGC-3' and 5-HTTLPRreverse: 5'-GAGGGACTGAGCTGGACAACCAC-3') previously reported by Heils et al. (1996) were employed. Briefly, PCR amplification was carried out in a final volume of $25 \mu \mathrm{L}$ containing 50-100 ng genomic DNA template, $0.2 \mathrm{mM}$ each deoxyribonucleotide, $0.2 \mu \mathrm{M}$ forward and reverse primers, 2X PCRx enhancer solution, $20 \mathrm{mM}$ Tris-HCl, $\mathrm{pH} 8.4,50 \mathrm{mM} \mathrm{KCl}, 1.5 \mathrm{mM}$ $\mathrm{MgSO}_{4}$ and $1.25 \mathrm{U} \mathrm{Taq}$ DNA polymerase. After denaturing for $2 \mathrm{~min}$ at $95^{\circ} \mathrm{C}$, the desired DNA fragment was amplified for 35 cycles of $95^{\circ} \mathrm{C}$ for $30 \mathrm{~s}, 60^{\circ} \mathrm{C}$ for $30 \mathrm{~s}$, and $68^{\circ} \mathrm{C}$ for 1 min with a final extension at $68^{\circ} \mathrm{C}$ for $10 \mathrm{~min}$. PCR products along with 100-bp DNA ladder (New England Biolabs, Beverly, MA, USA) were electrophored on 3.5\% agarose gel and visualized by ethidium bromide staining. The s allele is $44 \mathrm{bp}$ shorter than the 1 allele because of a deletion.

\section{Statistical analysis}

Gender data were compared by the chi-square $\left(\chi^{2}\right)$ test in contingency tables. Difference in age data between case and control groups was examined using the unpaired Student $t$-test. Hardy-Weinberg equilibrium (HWE) for the genotype distributions was estimated by the $\chi^{2}$ test. Allele and genotype frequencies were compared between the group of patients with psoriasis and healthy controls using the $\chi^{2}$ test with Yates correction. Additionally, comparisons between the subset of psoriatic patients by either onset or severity of disease and the healthy control group were performed. A $\mathrm{P}$ value of $<0.05$ was considered to be significant. Odds ratios with a 95\% confidence interval were calculated using EpiCalc 2000 version 1.02 (http://www.brixtonhealth.com/epicalc.html).

\section{RESULTS}

Characteristics of patients with psoriasis and healthy controls were compared with regard to gender and age (Table 1). There was no statistically significant difference between these two groups with respect to gender $(\mathrm{P}=0.909)$. Nevertheless, there was a difference in age between the two groups $(\mathrm{P}<0.001)$. In particular, proportions of 30 -year-olds were high in the control group, whereas proportions of older subjects were elevated in the patient group.

\begin{tabular}{|c|c|c|c|c|c|c|}
\hline & Psoriasis* & $\begin{array}{l}\text { Early-onset } \\
\text { psoriasis }\end{array}$ & $\begin{array}{c}\text { Late-onset } \\
\text { psoriasis }\end{array}$ & PASI $<10$ & $\mathrm{PASI} \geq 10$ & $\begin{array}{l}\text { Healthy } \\
\text { controls }\end{array}$ \\
\hline Total number of subjects & 156 & 99 & 51 & 93 & 60 & 156 \\
\hline Males, N (\%) & $88(56.41)$ & $51(51.52)$ & $33(64.71)$ & $49(52.69)$ & $37(61.67)$ & $86(55.13)$ \\
\hline Females, N (\%) & $68(43.59)$ & $48(48.48)$ & $18(35.29)$ & $44(47.31)$ & $23(38.33)$ & $70(44.87)$ \\
\hline $\begin{array}{l}\text { Age at enrolment } \\
\text { (years), mean (SD) }\end{array}$ & $46.32(14.69)$ & $39.96(11.61)$ & $58.62(12.61)$ & $46.68(15.45)$ & $45.78(13.76)$ & $36.52(10.94)$ \\
\hline $\begin{array}{l}\text { Age at onset of symptoms } \\
\text { (years), mean (SD) }\end{array}$ & $35.96(15.50)$ & $27.16(8.52)$ & $53.20(10.93)$ & $37.69(15.96)$ & $33.36(14.54)$ & - \\
\hline
\end{tabular}

*Clinical data of only a few psoriatic patients were not available with respect to either onset or severity of disease. PASI $=$ Psoriasis Area and Severity Index.

The 5-HTTLPR genotype distributions and allele frequencies for the two groups are shown in Table 2. Their genotype distributions were in HWE in both patients with psoriasis $\left(\chi^{2}\right.$ $=0.31$, d.f. $=1, \mathrm{P}=0.580)$ and healthy controls $\left(\chi^{2}=1.20\right.$, d.f. $\left.=1, \mathrm{P}=0.274\right)$. In the associa- 
tion study, there was no significant difference between the two groups with respect to either genotype distributions or allele frequencies. In analysis of the subsets of psoriatic patients classified by onset and severity of disease, no significant difference was observed between these subgroups and healthy controls.

\begin{tabular}{|c|c|c|c|c|c|c|c|c|c|c|}
\hline \multirow[t]{2}{*}{ Variables } & \multicolumn{5}{|c|}{ Genotype } & \multicolumn{5}{|c|}{ Allele } \\
\hline & ss & $\mathrm{sl}$ & 11 & $\chi^{2}$, d.f. $=2$ & $\mathrm{P}$ & $\mathrm{s}$ & 1 & $\chi^{2}$, d.f. $=1$ & $\mathrm{P}$ & OR $(95 \% \mathrm{CI})$ \\
\hline $\begin{array}{l}\text { Psoriasis } \\
\quad(\mathrm{N}=156)\end{array}$ & $\begin{array}{c}79 \\
(50.64 \%)\end{array}$ & $\begin{array}{c}62 \\
(39.74 \%)\end{array}$ & $\begin{array}{c}15 \\
(9.62 \%)\end{array}$ & 1.39 & 0.500 & $\begin{array}{c}220 \\
(70.51 \%)\end{array}$ & $\begin{array}{c}92 \\
(29.49 \%)\end{array}$ & 0.00 & 1.000 & $\begin{array}{c}1.02 \\
(0.72-1.43)\end{array}$ \\
\hline $\begin{array}{c}\text { Early-onset } \\
(\mathrm{N}=99)\end{array}$ & $\begin{array}{c}52 \\
(52.53 \%)\end{array}$ & $\begin{array}{c}39 \\
(39.39 \%)\end{array}$ & $\begin{array}{c}8 \\
(8.08 \%)\end{array}$ & 0.93 & 0.628 & $\begin{array}{c}143 \\
(72.22 \%)\end{array}$ & $\begin{array}{c}55 \\
(27.78 \%)\end{array}$ & 0.15 & 0.695 & $\begin{array}{c}1.10 \\
(0.74-1.64)\end{array}$ \\
\hline $\begin{array}{l}\text { Late-onset } \\
(\mathrm{N}=51)\end{array}$ & $\begin{array}{c}24 \\
(47.06 \%)\end{array}$ & $\begin{array}{c}21 \\
(41.18 \%)\end{array}$ & $\begin{array}{c}6 \\
(11.76 \%)\end{array}$ & 1.20 & 0.548 & $\begin{array}{c}69 \\
(67.65 \%)\end{array}$ & $\begin{array}{c}33 \\
(32.35 \%)\end{array}$ & 0.13 & 0.718 & $\begin{array}{c}0.89 \\
(0.55-1.44)\end{array}$ \\
\hline $\begin{array}{c}\text { PASI < } 10 \\
(\mathrm{~N}=93)\end{array}$ & $\begin{array}{c}39 \\
(41.94 \%)\end{array}$ & $\begin{array}{c}44 \\
(47.31 \%)\end{array}$ & $\begin{array}{c}10 \\
(10.75 \%)\end{array}$ & 1.38 & 0.503 & $\begin{array}{c}122 \\
(65.59 \%)\end{array}$ & $\begin{array}{c}64 \\
(34.41 \%)\end{array}$ & 0.94 & 0.332 & $\begin{array}{c}0.81 \\
(0.55-1.19)\end{array}$ \\
\hline $\begin{aligned} \text { PASI } & \geq 10 \\
(\mathrm{~N} & =60)\end{aligned}$ & $\begin{array}{c}37 \\
(62.71 \%)\end{array}$ & $\begin{array}{c}18 \\
(30.51 \%)\end{array}$ & $\begin{array}{c}5 \\
(8.47 \%)\end{array}$ & 4.33 & 0.114 & $\begin{array}{c}92 \\
(76.67 \%)\end{array}$ & $\begin{array}{c}28 \\
(23.33 \%)\end{array}$ & 1.49 & 0.221 & $\begin{array}{c}1.39 \\
(0.86-2.27)\end{array}$ \\
\hline $\begin{array}{l}\text { Control } \\
\qquad(\mathrm{N}=156)\end{array}$ & $\begin{array}{c}74 \\
(47.44 \%)\end{array}$ & $\begin{array}{c}71 \\
(45.51 \%)\end{array}$ & $\begin{array}{c}11 \\
(7.05 \%)\end{array}$ & - & - & $\begin{array}{c}219 \\
(70.19 \%)\end{array}$ & $\begin{array}{c}93 \\
(29.81 \%)\end{array}$ & - & - & - \\
\hline
\end{tabular}

d.f. $=$ degrees of freedom; $\mathrm{OR}=$ odds ratio $\mathrm{CI}=$ confidence interval. PASI $=$ Psoriasis Area and Severity Index.

\section{DISCUSSION}

Regarding the importance of 5-HTTLPR in the regulation of 5-HTT activity, various groups have examined this functional promoter polymorphism for possible association with numerous disorders, particularly neuropsychiatric disorders. Psoriasis appears to be stressassociated, and it has been well documented that stress and stress-related hormones are closely connected to the serotonergic system. Only a few groups to date have attempted to prove the hypothesis that 5-HTTLPR polymorphism plays a part in psoriasis susceptibility. Recently, no association between 5-HTTLPR polymorphism and psoriasis was found in German Caucasian samples when comparing between all psoriatic cases and healthy controls, and no difference in genotype distributions was observed when taking different onsets of psoriasis into account (Mössner et al., 2009). Nevertheless, the association study between the 5-HTTLPR polymorphism and psoriasis severity has not been carried out. This should have already been addressed since there is scientific evidence for certain polymorphisms influencing disease severity in psoriasis (Kingo et al., 2003).

Notably, global variations in the allelic frequencies of the 5-HTTLPR polymorphism have been reported among European, European American, African American, Japanese, native American, Chinese, and African populations (Gelernter et al., 1997, 1999). To this end, association studies in distinct ethnic populations may reveal different results. Therefore, our present study aimed at investigating a potential association between 5-HTTLPR polymorphism and psoriasis in a Thai population. Regarding the allele frequencies of this polymorphism, our finding was in agreement with studies carried out in Asian populations, especially Chinese whose allele frequencies were 71 and 29\% for s and 1, respectively (Tsai et al., 2000; You et al., 2005). In contrast, analyses of the 5-HTTLPR polymorphism in Caucasian populations have showed 1 as the most common allelic type (Ospina-Duque et al., 2000; Haberstick et al., 2006; Mössner et al., 2009). In our present 
investigation, no significant association was found when comparing between healthy controls and either all psoriatic patients or psoriatic patients classified by onset of psoriasis, thus being in agreement with the study by Mössner and colleagues (2009) in a German population.

Recently, it has been reported that certain genotypes of cytokine gene polymorphisms are more predominant in psoriatic cases with moderate severity (Settin et al., 2009). This particular finding suggests that certain genetic variations may be considered as severity-modifying polymorphisms with respect to psoriasis. In fact, the patients can be generally divided into three groups (mild, moderate and severe) according to the PASI score. In our investigation, we classified psoriatic patients into two groups only as a group of patients with severe psoriasis would be too small, thus combining patients with moderate and severe psoriasis in the same group. Nevertheless, an association between the 5-HTTLPR polymorphism and psoriasis severity was not found.

Regarding a point of concern, the observed difference in age between patients with psoriasis and healthy controls in both our present study and the German study may affect the outcome in the association test. For instance, certain healthy controls with young ages at enrolment may develop psoriasis in the future. Nonetheless, the age-influenced outcome may be unlikely since both studies showed no significant association even between the 5-HTTLPR polymorphism and early-onset psoriasis. In fact, the numbers of psoriatic patients with early onset were predominant since they accounted for approximately 60 and $70 \%$ of the entire patient group in our current study and the German study, respectively.

In conclusion, the present study found no significant differences in genotype distributions and allele frequencies of 5-HTTLPR polymorphism when patients with psoriasis, either overall or subsets classified by onset and severity, were compared with healthy controls. Nevertheless, we recommend that future research should explore not only larger sample sizes, but also distinct ethnic samples. Given the potential role of the serotonergic system in the etiology of psoriasis, studies on numerous functionally relevant genetic variations of the major genes of this system should not be forgotten. Particularly, discovering or developing drugs influencing the serotonergic system might be a desired mission since these types of chemicals, such as selective 5-HT reuptake inhibitors, are commercially available and commonly utilized for therapeutic purposes.

\section{ACKNOWLEDGMENTS}

Research supported by the Royal Thai Government Research Fund 2006 (to J. Wongpiyabovorn) and the Chulalongkorn University Centenary Academic Development Project \#2008-2012 (to T. Tencomnao). The authors gratefully acknowledge the active cooperation of all participants. We are indebted to Anchalee Prasansuklab and Varaporn Rakkhitawatthana for their technical assistance.

\section{REFERENCES}

Amara SG and Pacholczyk T (1991). Sodium-dependent neurotransmitter reuptake systems. Curr. Opin. Neurobiol. 1: 84-90.

Azmitia EC (2001). Modern views on an ancient chemical: serotonin effects on cell proliferation, maturation, and apoptosis. Brain Res. Bull. 56: 413-424.

Azmitia EC Jr and McEwen BS (1969). Corticosterone regulation of tryptophan hydroxylase in midbrain of the rat. Science 166: 1274-1276. 
Azmitia EC, Liao B and Chen YS (1993). Increase of tryptophan hydroxylase enzyme protein by dexamethasone in adrenalectomized rat midbrain. J. Neurosci. 13: 5041-5055.

Barth JH and Baker H (1986). Generalized pustular psoriasis precipitated by trazodone in the treatment of depression. $B r$. J. Dermatol. 115: 629-630.

Geba GP, Ptak W, Anderson GM, Paliwal V, et al. (1996). Delayed-type hypersensitivity in mast cell-deficient mice: dependence on platelets for expression of contact sensitivity. J. Immunol. 157: 557-565.

Gelernter J, Kranzler H and Cubells JF (1997). Serotonin transporter protein (SLC6A4) allele and haplotype frequencies and linkage disequilibria in African- and European-American and Japanese populations and in alcohol-dependent subjects. Hum. Genet. 101: 243-246.

Gelernter J, Cubells JF, Kidd JR, Pakstis AJ, et al. (1999). Population studies of polymorphisms of the serotonin transporter protein gene. Am. J. Med. Genet. 88: 61-66.

Griffiths CE and Richards HL (2001). Psychological influences in psoriasis. Clin. Exp. Dermatol. 26: 338-342.

Haberstick BC, Smolen A and Hewitt JK (2006). Family-based association test of the 5HTTLPR and aggressive behavior in a general population sample of children. Biol. Psychiatry 59: 836-843.

Heils A, Teufel A, Petri S, Stober G, et al. (1996). Allelic variation of human serotonin transporter gene expression. $J$. Neurochem. 66: 2621-2624.

Huang J, Li G, Xiang J, Yin D, et al. (2004). Immunohistochemical study of serotonin in lesions of psoriasis. Int. J. Dermatol. 43: 408-411.

Hwu WL, Yang CF, Fann CS, Chen CL, et al. (2005). Mapping of psoriasis to 17q terminus. J. Med. Genet. 42: 152-158.

Kasperska-Zajac A, Brzoza Z and Rogala B (2008). Platelet function in cutaneous diseases. Platelets 19: 317-321.

Kingo K, Koks S, Silm H and Vasar E (2003). IL-10 promoter polymorphisms influence disease severity and course in psoriasis. Genes Immun. 4: 455-457.

Lesch KP, Wolozin BL, Murphy DL and Reiderer P (1993). Primary structure of the human platelet serotonin uptake site: identity with the brain serotonin transporter. J. Neurochem. 60: 2319-2322.

Lesch KP, Balling U, Gross J, Strauss K, et al. (1994). Organization of the human serotonin transporter gene. J. Neural Transm. Gen. Sect. 95: 157-162.

Lesch KP, Bengel D, Heils A, Sabol SZ, et al. (1996). Association of anxiety-related traits with a polymorphism in the serotonin transporter gene regulatory region. Science 274: 1527-1531.

Mortensen OV, Thomassen M, Larsen MB, Whittemore SR, et al. (1999). Functional analysis of a novel human serotonin transporter gene promoter in immortalized raphe cells. Brain Res. Mol. Brain Res. 68: 141-148.

Mössner R, Stiens G, Konig IR, Schmidt D, et al. (2009). Analysis of a functional serotonin transporter promoter polymorphism in psoriasis vulgaris. Arch. Dermatol. Res. 301: 443-447.

Nordlind K, Thorslund K, Lonne-Rahm S, Mohabbati S, et al. (2006). Expression of serotonergic receptors in psoriatic skin. Arch. Dermatol. Res. 298: 99-106.

O’Connell PJ, Wang X, Leon-Ponte M, Griffiths C, et al. (2006). A novel form of immune signaling revealed by transmission of the inflammatory mediator serotonin between dendritic cells and T cells. Blood 107: 1010-1017.

O'Sullivan RL, Lipper G and Lerner EA (1998). The neuro-immuno-cutaneous-endocrine network: relationship of mind and skin. Arch. Dermatol. 134: 1431-1435.

Osborne SF, Stafford L and Orr KG (2002). Paroxetine-associated psoriasis. Am. J. Psychiatry 159: 2113.

Ospina-Duque J, Duque C, Carvajal-Carmona L, Ortiz-Barrientos D, et al. (2000). An association study of bipolar mood disorder (type I) with the 5-HTTLPR serotonin transporter polymorphism in a human population isolate from Colombia. Neurosci. Lett. 292: 199-202.

Peters BP, Weissman FG and Gill MA (2000). Pathophysiology and treatment of psoriasis. Am. J. Health Syst. Pharm. 57: 645-659.

Ramamoorthy S, Bauman AL, Moore KR, Han H, et al. (1993). Antidepressant- and cocaine-sensitive human serotonin transporter: molecular cloning, expression, and chromosomal localization. Proc. Natl. Acad. Sci. U. S. A. 90: 2542-2546.

Reich A and Szepietowski JC (2007). Mediators of pruritus in psoriasis. Mediators Inflamm. 2007: 64727.

Ronpirin C, Tencomnao T and Wongpiyabovorn J (2010). Association between the $-1438 \mathrm{~A} / \mathrm{G}$ polymorphism of the serotonin 2A receptor gene and late-onset psoriasis in a Thai population. Genet. Mol. Res. 9: 208-214.

Settin A, Hassan H, El-Baz R and Hassan T (2009). Association of cytokine gene polymorphisms with psoriasis in cases from the Nile Delta of Egypt. Acta Dermatovenerol. Alp Panonica. Adriat. 18: 105-112.

Tan Pei LL and Kwek SK (2010). Onset of psoriasis during therapy with fluoxetine. Gen. Hosp. Psychiatry 32: 446.

Tencomnao T, Ketboonlue K, Wongpiyabavorn J, Ronpirin C, et al. (2007). Analysis of autoantibodies to serotonin and serotonin levels in psoriasis. Chin. Med. J. 120 (Suppl 2): P07-P02.

Thorslund K, El-Nour H and Nordlind K (2009). The serotonin transporter protein is expressed in psoriasis, where it may

Genetics and Molecular Research 9 (4): 2275-2282 (2010)

CFUNPEC-RP www.funpecrp.com.br 
play a role in regulating apoptosis. Arch. Dermatol. Res. 301: 449-457.

Tomfohrde J, Silverman A, Barnes R, Fernandez-Vina MA, et al. (1994). Gene for familial psoriasis susceptibility mapped to the distal end of human chromosome 17q. Science 264: 1141-1145.

Tsai SJ, Hong CJ, Yu YW, Lin CH, et al. (2000). Association study of a functional serotonin transporter gene polymorphism with schizophrenia, psychopathology and clozapine response. Schizophr. Res. 44: 177-181.

You JS, Hu SY, Chen B and Zhang HG (2005). Serotonin transporter and tryptophan hydroxylase gene polymorphisms in Chinese patients with generalized anxiety disorder. Psychiatr. Genet. 15: 7-11. 